Guiné RPF, Duarte J, Ferrão AC, Ferreira M, Correia P, Cardoso AP, Bartkiene E, Szücs V, Nemes L, Ljubičić M, Černelič-Bizjak M, Isoldi K, EL Kenawy A, Ferreira V, Straumite E, Korzeniowska M, Vittadini E, Leal M, Frez-Muñoz L, Papageorgiou M, Djekić I. The eating motivations scale (EATMOT): development and validation by means of confirmatory factor analysis (CFA) and structural equation modelling (SEM). Zdr Varst. 2021;60(1):4-9. doi: 10.2478/sjph-2021-0002.

\title{
THE EATING MOTIVATIONS SCALE (EATMOT): DEVELOPMENT AND VALIDATION BY MEANS OF CONFIRMATORY FACTOR ANALYSIS (CFA) AND STRUCTURAL EQUATION MODELLING (SEM) LESTVICA MOTIVOV PREHRANJEVANJA (EATMOT): RAZVOJ IN VALIDACIJA INSTRUMENTA S KONFIRMATORNO FAKTORSKO ANALIZO (CFA) IN MODELIRANJEM STRUKTURNIH ENAČB (SEM)
}

\author{
Raquel P. F. GUINÉ1*, João DUARTE², Ana Cristina FERRÃO², Manuela FERREIRA², \\ Paula CORREIA ${ }^{2}$, Ana Paula CARDOSO 2 , Elena BARTKIENE ${ }^{3}$, Viktória SZÜCS ${ }^{4}$, \\ Levente NEMES ${ }^{4}$, Marija LJUBIČIĆ ${ }^{5}$, Maša ČERNELIČ-BIZJAK ${ }^{6}$, Kathy ISOLDI7, Ayman EL KENAWY ${ }^{8}$, \\ Vanessa FERREIRA ${ }^{9}$, Evita STRAUMITE ${ }^{10}$, Matgorzata KORZENIOWSKA ${ }^{11}$, \\ Elena VITTADINI ${ }^{12}$, Marcela LEAL ${ }^{13}$, Lucia FREZ-MUÑOZ ${ }^{14}$, Maria PAPAGEORGIOU ${ }^{15}$, Ilija DJEKIĆ ${ }^{15}$
}

${ }^{1}$ Instituto Politecnico de Viseu, Food Industry, Campus Politécnico, Repeses, Viseu, 3504-010, Portugal ${ }^{2}$ CI\&DETS Research Centre, Polytechnic Institute of Viseu, Viseu, 3504-010, Portugal

${ }^{3}$ Department of Food Safety and Quality, Lithuanian University of Health Sciences, Kaunas, Lithuania ${ }^{4}$ Directorate of Food Industry, Hungarian Chamber of Agriculture, Budapest, Hungary

${ }^{5}$ Department of Pediatrics, General Hospital Zadar, Croatia

${ }^{6}$ Faculty of Health Sciences, University of Primorska, Slovenia

${ }^{7}$ Department of Nutrition, School of Health Professions and Nursing, Long Island University, USA

${ }^{8}$ Department of Molecular Biology, Genetic Eng. and Biotechnology Institute, University of Sadat City, Egypt ${ }^{9}$ Department of Nutrition, UFMG University, Minas Gerais, Brazil

${ }^{10}$ Department of Food Technology, Latvia University of Life Sciences and Technologies, Jelgava, Latvia

${ }^{11}$ Wroctaw University of Environmental and Life Sciences, Wrocław, Poland

${ }^{12} \mathrm{School}$ of Biosciences and Veterinary Medicine, University of Camerino, Italy

${ }^{13}$ School of Nutrition, Faculty of Health Sciences, Maimonides University, Argentina ${ }^{14}$ Food Quality and Design Group, Wageningen University \& Research, The Netherlands ${ }^{15}$ Faculty of Agriculture, University of Belgrade, Serbia

Received: Jan 22, 2020

Accepted: Oct 5, 2020

\section{ABSTRACT}

Keywords: eating determinants, healthy diet, emotions, feeding behaviour, socio-cultural environment, instrument validation

\section{IZVLEČEK}

Ključne besede: determinante prehranjevanja, zdrava prehrana, čustva, prehranjevalno vedenje, družbenokulturno okolje, preverjanje instrumentov
Introduction: The objective was to develop and validate an instrument that measures different determinants of people's food choices and simultaneously accounts for a variety of factors: health, emotions, price and availability, society and culture, environment and politics, and marketing and advertising.

Methods: This is a cross-sectional study focusing on food choice determinants. It was carried out in 16 countries in 2017 and 2018. This study included 11,960 volunteer adult participants from different countries. The data was validated using Confirmatory Factor Analysis (CFA) and Structural Equation Modelling (SEM).

Results: Validation using CFA with SEM revealed that multi-factor modelling produced first- and second-order models that could be used to define the EATMOT scale, the first presenting better fitting indices, with the goodness-of-fit and comparative-fit indices very close to 1 , as well as root-mean-square-error-of-approximation, root-mean-square-residual and standardised-root-mean-square-residual at practically zero.

Conclusion: The validated EATMOT scale guarantees confidence in the information obtained through this instrument, and can be used in future studies to better understand food choice determinants in different geographical areas and help plan strategies to improve healthy eating patterns and diminish the burden of non-communicable diseases.

Uvod: Cilj študije je bil razviti in preveriti instrument za merjenje različnih determinant, ki lahko vplivajo na izbiro živil in hkrati upoštevajo različne dejavnike: zdravje, čustva, ceno in razpoložljivost, družbo in kulturo, okolje in politiko ali trženje in oglase.

Metode: To je presečna študija, ki se osredotoča na determinante izbire živil in je bila med letoma 2017 in 2018 izvedena $v 16$ državah. Ta študija je vključevala 11.960 odraslih prostovoljcev iz različnih držav. Podatke smo preverili $s$ konfirmatorno faktorsko analizo (CFA) in modeliranjem strukturnih enačb (SEM).

Rezultati: Preverjanje S CFA in SEM je pokazalo, da so pri večfaktorskem modeliranju nastali modeli prvega in drugega reda, ki se lahko uporabljajo za opredelitev lestvice EATMOT, pri čemer modeli prvega reda predstavljajo primernejše kazalnike, in sicer sta indeks skladnosti (angl. goodness-of-fit index) in primerjalni indeks prileganja (angl. comparative-fit index) zelo blizu vrednosti 1, koren povprečne kvadrirane napake približka (angl. root-mean-squareerror-of-approximation), koren povprečja kvadriranih ostankov (angl. root-mean-square-residual) in standardizirani koren povprečja kvadriranih ostankov (angl. standardized-root-mean-square-residual) pa so praktično enaki nič.

Zaključek: Validirana lestvica EATMOT zagotavlja verodostojnost podatkov, pridobljenih s tem instrumentom, in se lahko uporablja $v$ prihodnjih študijah za boljše razumevanje determinant izbire živil na različnih geografskih območjih ter načrtovanje strategij za izboljšanje zdravih prehranjevalnih vzorcev in zmanjšanje bremena nenalezljivih bolezni. 


\section{INTRODUCTION}

A healthy diet is one of the pillars for the maintenance of health, and has been addressed by many scientific studies (1). However, because people's food choices are multidimensional, being influenced by a range of interconnected factors, choosing to follow a healthy diet is not a simple task (2). The main factors that influence food choices include biological, cultural, economic, psychological and marketing factors, as well as health and ethical concerns $(3,4)$. Furthermore, consumers are becoming ever more aware of the effects that their diets may have on the environment (5). Food choices are also affected by determinants related to the product itself, such as appearance, taste, smell and textural characteristics (2). In fact, food choice is contextual, dynamic and integrated into social life (6). Understanding the motivations underlying people's food choices is important because it relates to so many current social and economic issues. It is therefore essential that media messages and health promotional campaigns be developed that can target people effectively and encourage them to adopt a healthy lifestyle $(3,7)$.

There is a wide range of instruments that explore people's food choices by focusing on core motives. Of these, the Food Choice Questionnaire is the most commonly used. This was originally created to measure nine distinct food choice motives: health, mood, convenience, sensory appeal, natural content, price, weight, control, familiarity and ethical concerns (8). Lindeman and Väänänen (9) subsequently added three more food choice motives: animal welfare, environmental concerns, and political and religious values. Other instruments focus on different eating motivations, such as the Motivations to Eat Scale (10), the Dutch Eating Behaviour Questionnaire (11), and the Health and Taste Attitudes Questionnaire (12). However, no single instrument is relevant to everyone (13) and, in all of these instruments, other important motives for food choices are not considered.

In light of the importance of the different determinants that can influence people's food choices, an instrument was developed that aimed to capture the different dimensions of this important health-related behaviour. The present study was undertaken to develop and validate this new instrument, "EATING MOTIVATIONS" (EATMOT), which accounts simultaneously for a variety of different factors.

\section{METHODS}

\subsection{Instrument}

The self-report response questionnaire was designed to gather information about the different determinants that could influence people's food choices. Different statements were prepared that addressed each of the topics. The measuring instrument included 49 questions (included in the supplementary material), distributed as follows: Health motivations: 10; Emotional motivations: 9; Economic and availability motivations: 7; Social and cultural motivations: 9; Environmental and political motivations: 7; Marketing and commercial motivations: 7. Respondents were asked to indicate their level of agreement with each given statement by using a 5-point ordinal Likert scale, where each value had the following meaning: 1 - strongly disagree, 2 - disagree, 3 - neither agree nor disagree, 4 agree and 5 - strongly agree. The questionnaire was only given to adult participants on a voluntary basis (following an informed consent procedure).

\subsection{Sample}

The sample consisted of 11,960 participants from 16 countries (Argentina - 4\%, Brazil - 6\%, Croatia - 13\%, Egypt - $7 \%$, Greece - 4\%, Hungary - 4\%, Italy - 5\%, Latvia - $5 \%$, Lithuania - 4\%, Netherlands - 4\%, Poland - 5\%, Portugal $11 \%$, Serbia - 4\%, Slovenia - 9\%, Romania - 7\%, United States - 7\%). Women accounted for $71.4 \%$ and men for $28.6 \%$ of participants. The participants were aged between 18 and 90 , with an average age of $34 \pm 14$ years.

\subsection{Statistical analysis}

Validation of the psychometric quality of the instrument was achieved through reliability and validity tests, following the recommended statistical analyses, which provided information useful for understanding the degree of generalisation of the results obtained from the sample used. The metric properties of the instruments were analysed by taking into account the distribution of items, the assumptions of reliability and validity studies. These are fundamental aspects that any data collection instrument must contain in order to guarantee the quality of the information gathered. In the distribution of the items, the reference values for the asymmetry parameters considered were: skewness $\leq 3$ and kurtosis $\leq 7$ (14).

Reliability studies were conducted in order to evaluate the internal consistency of the items. Pearson's linear correlation coefficient ( $r$ ) was determined for the different items, with an overall score when it did not contain the item as well as Cronbach's alpha.

AMOS 24 (Analysis of Moment Structures) software was used for the analysis of the CFA model, with the following parameters evaluated: (i) the factorial weights $(\lambda)$ and represented by the unidirectional arrows of the factors (latent variables) for the indicators (manifest variables); (ii) the variances and covariances of the individual reliability of the indicators $(\delta)$ and represented by unidirectional arrows linking the indicators to the errors; (iii) the variances and covariances of the factors phi (Ф); and (iv) the error correlations, represented using (ס) and symbolised by bidirectional arrows when covariance 
is included in the errors, indicating that the covariance between the two indicators is due to reasons not explained by the factor (method effects). Bidirectional arrows are also used to symbolise covariance between factors (15).

For acceptance of the CFA model, the following was observed: (i) the interpretability, weight and statistical significance of the parameters (ii) the modification indexes proposed by AMOS and (iii) the model adjustment indicators (15).

Regarding the interpretation of the parameters, the reference values considered are: correlation between the factors $(\Phi)$ - the higher the coefficients, the better; regression coefficients $(\lambda)$ - values greater than 0.50 ; individual reliability of indicators $(\delta)$ - coefficients equal to or greater than 0.25 ; statistical significance - $p$-value lower than 0.05 (14).

Since the modification indices are very sensitive to the size of the sample, the orientation was provided by the change values proposed by the software, and the adjustment of the model was performed using reference values greater than 11. The following reference values were adopted for the indicators of the quality of adjustment of the model $(16,17)$ :

(a) The values used for absolute fit were as follows:

- Ratio of chi-square and degrees of freedom $\left(\chi^{2} / \mathrm{df}\right)$ : if $\left(x^{2} / d f\right)$ is equal to 1 , the fit is perfect, for values lower than 2 the fit is good, for values lower than 5 the fit is acceptable, and for values greater than 5 the fit is unacceptable.

- Root mean square residual (RMR): the lower the RMR value, the better the fit, i.e. when $R M R=0$, this indicates a perfect fit.

- Standardised root mean square residual (SRMR): a value of zero indicates a perfect fit, and values lower than 0.08 are generally considered a good fit.

- Goodness of fit index (GFI): values around 0.95 or higher are recommended (with a maximum value equal to 1 ), but values over 0.90 are considered a good fit.

(b) Values for relative fit:

- Comparative fit index (CFI), which is an additional comparative index of adjustment to the model: values lower than 0.90 indicate a poor fit, values between 0.90 and 0.95 indicate a good adjustment, and values above 0.95 indicate a very good adjustment (maximum value of 1 corresponds to a perfect fit). This index is independent of the sample size.

(c) Population discrepancy index:

- Root mean square error of approximation (RMSEA): reference values for the RMSEA, with a $90 \%$ confidence interval, between 0.05 and 0.08 mean the adjustment is good, while it is considered very good when the index is lower than 0.05 .
As additional measures to verify the quality of the model, the composite reliability (CR), the mean extracted variance $(M E V)$ and the discriminant validity $(\Phi)$ for each of the factors were determined.

Composite reliability tells us whether the items constitute manifestations of the factor. As reference values, indexes higher than 0.70 are suggested, although lower values may be acceptable for exploratory investigations (17). The mean extracted variance (MEV) evaluates the convergent validity that occurs when the indicators, which are a reflection of a factor, saturate strongly in this factor. Values greater than or equal to 0.50 are considered to be indicative of adequate validity, but this limit can be adjusted to 0.40 in exploratory analyses (17). The parameters $(\Phi)$ allow us to evaluate the discriminant validity of the factors, and their values $\left(R^{2}\right)$ must not be higher than the MEV of each of the factors.

\section{RESULTS}

\subsection{First-order model}

Structural Equation Modelling has been used by a number of researchers, including Guiné et al. (18) for the development of a scale to measure knowledge about dietary fibre, and Sidali et al. (19) for assessing the acceptance by Western students of insect-based food from the Ecuadorian Amazon rainforest. SEM has also been used by Lagerkvist et al. (20) to estimate a construct that could explain consumer confidence in food safety practices along the food supply chain, and by Lim et al. (21) to assess the relationship between food safety knowledge, attitude and behaviours among household food preparers. Ting et al. (22) have used SEM to model tourists' food consumption intentions at their destination.

For this study, a confirmatory factorial analysis (CFA) was carried out to determine how the items considered in the six groups consigned eating motivations as a multidimensional variable. Following this assumption, the AFC was carried out using the items that had been validated in each of the groups, excluding those items that did not meet the criteria for inclusion according to the indicators defined previously. Figure 1 illustrates the results obtained including the modification indices proposed by AMOS. According to the trajectories of the items with the corresponding factors, it is determined that all items have factor weights greater than 0.40 . The goodness of fit indices for the overall adjustment indicate adequate indices (Table 1 ), except for the chi-square ratio $\left(\chi^{2} / d f=25211\right)$, but with $\mathrm{GFI}$ and CFI very close to $1(0.968$ and 0.943 , respectively) and with RMSEA, RMR and SRMR very close to zero $(0.045,0.055$ and 0.044 respectively). 


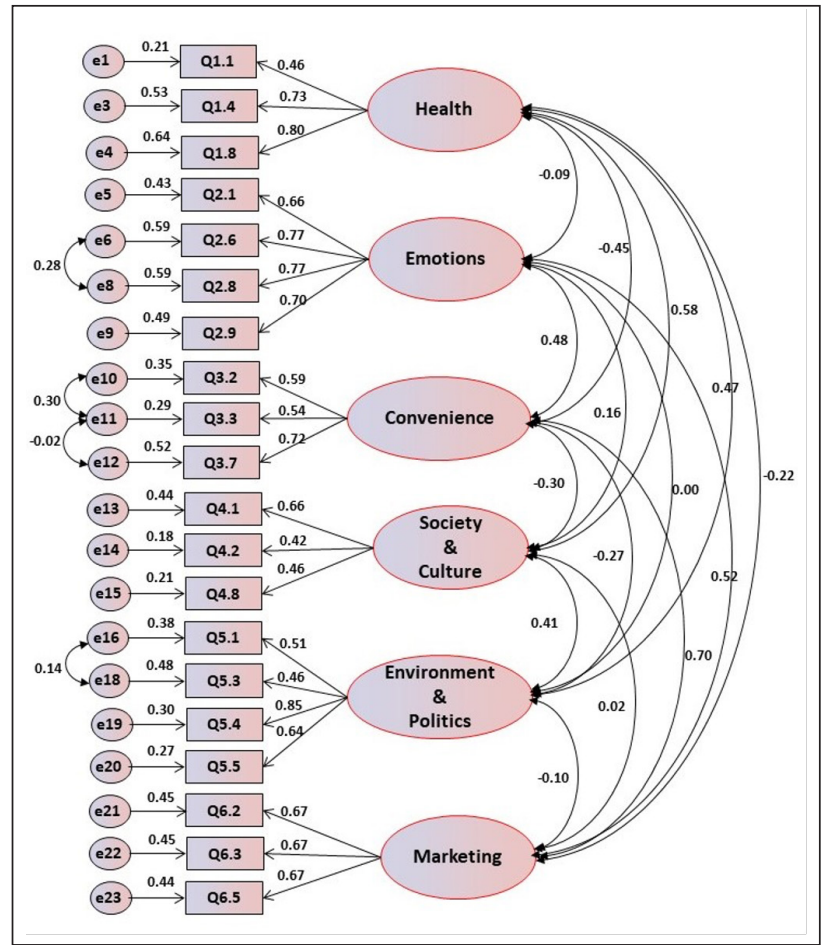

Figure 1. First-order multidimensional model for the Eating Motivations Scale.

\subsection{Second-order model}

Given that moderate and negative correlations have been found between some factors, a second-order model was further tested to define the eating motivations (EATMOT), which is represented in Figure 2. The results show correlations ranging from a perfect negative correlation between EATMOT and convenience stimuli, to a positive correlation between EATMOT and health factors (0.46), explaining $21 \%$ of the variability. Furthermore, also negative correlations were found between EATMOT and marketing ( $r=-0.69$, explaining $48 \%$ of variability) and between EATMOT and emotions ( $r=-0.48,23 \%$ variance explained). On the other hand, additional positive correlations were found between EATMOT and social/ cultural determinants ( $r=0.27,7 \% \mathrm{VE})$ and between EATMOT and environmental/political influences $(0.30,9 \%$ VE). However, the goodness of fit indices for the global adjustment to the second-order model became poorer when compared to the first-order model, just with the exception of the chi-square ratio (Table 1). The results in Table 1 show that in the second-order model only the
GFI and RMSEA indices remain adequate, while the CFI and RMR items are unsuitable and the chi-square ratio is still inadequate, although lower. This implies that some care must be taken when considering the second-order EATMOT model.

The study was completed by analysing the results of composite reliability (CR) and convergent validity (MEV). By observing the values in Table 2 it was concluded that, with the exception of convenience and social factors, which present reasonable internal consistency, all the others have good internal consistency indices, since they are higher than 0.70 . On the other hand, the values of MEV do not allow the conclusion of the convergent validity in the studied sample, since some values are lower than the threshold considered of 0.40 , like for example the society and environment factors ( 0.257 and 0.397 , respectively). The stratified composite reliability is good $(0.933)$ being the convergent validity acceptable (0.419) (17).

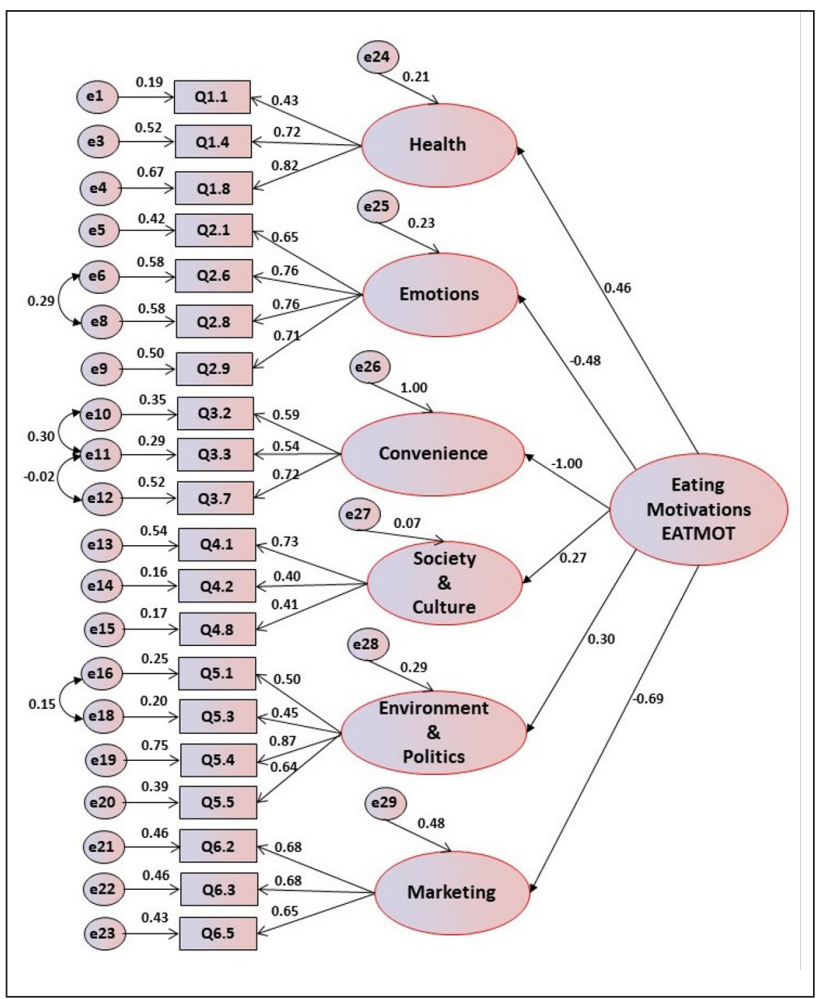

Figure 2. Second-order multidimensional model for the Eating Motivations Scale.

Table 1. Goodness of fit indices of the CFA for the multidimensional models.

\begin{tabular}{lcccccc}
\hline Rank & $\chi^{2} / d f$ & GFI & CFI & RMSEA & RMR & SRMR \\
\hline First-order model (with modification indices) & 25211 & 0.968 & 0.943 & 0.045 & 0.055 & 0.044 \\
Second-order model & 49.170 & 0.930 & 0.881 & 0.063 & 0.101 & 0.086 \\
\hline
\end{tabular}


Table 2. Parameters for internal consistency evaluation.

\begin{tabular}{lcl}
\hline Dimensions & $C R$ & MEV \\
\hline Health & 0.708 & 0.459 \\
Emotions & 0.814 & 0.524 \\
Convenience & 0.647 & 0.498 \\
Society & 0.522 & 0.257 \\
Environment & 0.713 & 0.397 \\
Marketing & 0.709 & 0.449 \\
\hline
\end{tabular}

\section{DISCUSSION}

Many worldwide health issues are related, among other civilisational factors, to: inappropriate eating behaviours; deliberately opting to eat based on emotional determinants rather than making healthier choices (or alternatively, making poor choices due to a lack of reliable information); influence of environmental concerns, such as respect for a sustainable food chain; political matters such as respect for human rights or animal welfare; convenience (e.g. lack of time to prepare meals and shop for fresher products). Strategies to improve the general health status of the population rely on an appropriate diagnosis of those manageable factors that contribute to disease in order to adjust educational policies and targeted campaigns aimed at changing inadequate eating behaviours. In this sense, the present study, which focuses on six groups of motivations that condition food choices, highlights a validated instrument for assessing people's eating motivations.

The confirmatory factor analysis carried out in the present work to validate the EATMOT scale indicated that the great majority of the 49 original questions in the survey instrument did not reveal adequate consistency. They were therefore not considered in the final model. In total, only 20 questions were found to be appropriate, i.e. approximately $40 \%$ of the original survey questions. These results may have been influenced by the sensitive nature of many of the questions, which might have led to some difficulty in answering them truly or unequivocally, particularly as this is a self-response, nonguided questionnaire. Questions that were believed to be important for measuring eating motivations and food choices were therefore in practice answered in ways that proved to be inconsistent with the factors considered. Moreover, the use of different languages might have been a drawback, since it involved a translation from English to various different native languages (although a backtranslation process was employed to minimise the potential for misinterpretation). Solid results were nevertheless produced by the study, particularly for the retained questions. This was due to the high number of participants (almost 12,000), who came from different demographic categories in terms of age, gender, profession, and social and cultural influences, and from a fairly high number of countries (16) in different continents (Europe, Africa, America). For this reason, the EATMOT scale developed and validated in this study can be interpreted as being of global coverage and applicability.

\section{CONCLUSION}

This study investigated the eating motivations of nearly 12,000 individuals from around the world and provided data for validation of the EATMOT scale by means of CFA with SEM, which includes 20 items distributed within the different categories considered: health aspects, emotional statuses, economic and availability motivations, social and cultural influences, environmental and political determinants, and marketing and advertising.

Both the first- and second-order multi-factor models resulting from the CFA included the six dimensions considered. While both models could be accepted for the purposes of defining the EATMOT scale, the goodness of fit indices were slightly less satisfactory for the secondorder model compared with the first-order model, which presented good quality for all indicators, with the exception of the chi-square ratio.

The validated EATMOT scale provides a high degree of confidence in the information obtained through such questions, in this study or in future studies. This may be used to better understand the food choice determinants in different geographical areas, and to help plan strategies to improve healthy eating patterns and diminish the burden of non-communicable diseases.

\section{ACKNOWLEDGMENT}

This work was prepared in the ambit of the multinational project EATMOT from CI\&DETS Research Centre (IPV Viseu, Portugal) with reference PROJ/CI\&DETS/2016/0008 and also project PROJ/CI\&DETS/CGD/0012.

\section{CONFLICTS OF INTEREST}

The authors declare that no conflicts of interest exist.

\section{FUNDING}

This work was funded by National Funds through the FCT - Foundation for Science and Technology, I.P., within the scope of the project Ref ${ }^{a}$ UIDB/00681/2020. Furthermore, we would like to thank the CERNAS Research Centre and the Polytechnic Institute of Viseu for their support. 


\section{ETHICAL APPROVAL}

\section{Received from the Ethical Committee ESSV under reference no 04/2017.}

\section{REFERENCES}

1. Kraus A, Annunziata A, Vecchio R. Sociodemographic factors differentiating the consumer and the motivations for functional food consumption. J Am Coll Nutr. 2017;36:116-26. doi: 10.1080/07315724.2016.1228489.

2. Dikmen D, İnan-Eroğlu E, Göktaș Z, Barut-Uyar B, Karabulut E. Validation of a Turkish version of the food choice questionnaire. Food Qual Prefer. 2016;52:81-6. doi: 10.1016/j.foodqual.2016.03.016.

3. Freedman I. Cultural specificity in food choice - the case of ethnography in Japan. Appetite. 2016;96:138-46. doi: 10.1016/j.appet.2015.09.006.

4. Markovina J, Stewart-Knox BJ, Rankin A, Gibney M, de Almeida MDV, Fischer A, et al. Food4Me study: validity and reliability of Food Choice Questionnaire in 9 European countries. Food Qual Prefer. 2015:45:2632. doi: 10.1016/j.foodqual.2015.05.002.

5. De Marchi E, Caputo V, Nayga RM, Banterle A. Time preferences and food choices: evidence from a choice experiment. Food Policy. 2016;62:99-109. doi: 10.1016/j.foodpol.2016.05.004.

6. Ditlevsen K, Sandøe P, Lassen J. Healthy food is nutritious, but organic food is healthy because it is pure: the negotiation of healthy food choices by Danish consumers of organic food. Food Qual Prefer. 2019;71:46-53. doi: 10.1016/j.foodqual.2018.06.001.

7. Milošević J, Žeželj I, Gorton M, Barjolle D. Understanding the motives for food choice in Western Balkan countries. Appetite. 2012;58:20514. doi: 10.1016/j.appet.2011.09.012.

8. Steptoe A, Pollard TM, Wardle J. Development of a measure of the motives underlying the selection of food: the food choice questionnaire. Appetite. 1995;25:267-84. doi: 10.1006/appe.1995.0061.

9. Lindeman $M$, Väänänen $M$. Measurement of ethical food choice motives. Appetite. 2000;34:55-9. doi: 10.1006/appe.1999.0293.

10. Jackson B, Lynne Cooper M, Mintz L, Albino A. Motivations to eat: scale development and validation. J Res Personal. 2003;37:297-318. doi: 10.1016/S0092-6566(02)00574-3.

11. van Strien T, Frijters JER, Bergers GPA, Defares PB. The Dutch Eating Behavior Questionnaire (DEBQ) for assessment of restrained, emotional, and external eating behavior. Int J Eat Disord. 1986;5:295-315. doi: 10.1002/1098-108X(198602)5:2<295::AID-EAT2260050209>3.0.CO;2-T.

12. Roininen K, Lähteenmäki L, Tuorila H. Quantification of consumer attitudes to health and hedonic characteristics of foods. Appetite. 1999;33:71-88. doi: 10.1006/appe.1999.0232.

13. Ohri-Vachaspati P, Leviton LC. Measuring food environments: a guide to available instruments. Am J Health Promot AJHP. 2010;24:410-26. doi: 10.4278/ajhp.080909-LIT-190.

14. Marôco J. Análise Estatística com o SPSS statistics. 7 Ed. Brazil: Report Number, 2018.

15. Brown TA. Confirmatory factor analysis for applied research. 2 nd ed. New York: Guilford Press, 2015

16. Hair JF, Black WC, Babin BJ, Anderson RE. Multivariate data analysis. 7th ed. Upper Saddle River: Prentice Hall, 2009.

17. Marôco J. Análise de equações estruturais: fundamentos teóricos, software e aplicações. Lisboa: Report Number, 2014

18. Guiné R, Duarte J, Ferreira $M$, Correia $P$, Leal $M$, Rumbak I, et al. Knowledge about dietary fibres (KADF): development and validation of an evaluation instrument through structural equation modelling (SEM). Public Health. 2016;138:108-18. doi: 10.1016/j.puhe.2016.03.031.

19. Sidali KL, Pizzo S, Garrido-Pérez El, Schamel G. Between food delicacies and food taboos: a structural equation model to assess Western students' acceptance of Amazonian insect food. Food Res Int. 2019;115:83-9. doi: 10.1016/j.foodres.2018.07.027.

20. Lagerkvist CJ, Amuakwa-Mensah F, Tei Mensah J. How consumer confidence in food safety practices along the food supply chain determines food handling practices: evidence from Ghana. Food Control. 2018;93:265-73. doi: 10.1016/j.foodcont.2018.06.019.

21. Lim T-P, Chye F-Y, Sulaiman MR, Suki NM, Lee J-S. A structural modeling on food safety knowledge, attitude, and behaviour among Bum Bum Island community of Semporna, Sabah. Food Control. 2016;60:241-6. doi: 10.1016/j.foodcont.2015.07.042.

22. Ting H, Fam K-S, Jun Hwa JC, Richard JE, Xing N. Ethnic food consumption intention at the touring destination: the national and regional perspectives using multi-group analysis. Tour Manag. 2019;71:518-29. doi: 10.1016/j.tourman.2018.11.001. 